\title{
Factors Influencing Soil Erosion Control Practices Adoption in Centre of the Republic of Benin: Use of Multinomial Logistic
}

\author{
Akplo Tobi Moriaque ${ }^{1}$, Kouelo Alladassi Félix ${ }^{1}$, Houngnandan Pascal ${ }^{1}$, Azontondé Hessou Anastase ${ }^{2}$, \\ Agonvinon Mahugnon Socrate ${ }^{1} \&$ Bokossa Thiburce Sidoine ${ }^{3}$ \\ ${ }^{1}$ Laboratoire de Microbiologie des Sols et d'Ecologie Microbienne, Faculté des Sciences Agronomiques, \\ Université d'Abomey-Calavi-Université Nationale d'Agriculture, Abomey, Calavi, Benin \\ ${ }^{2}$ Laboratoire Sciences de Sol, Eau et Environnement, Institut National de Recherches Agricoles du Bénin, \\ Cotonou, Benin \\ ${ }^{3}$ Laboratoire de Biomathématiques et d'Estimations Forestières, Faculté des Sciences Agronomiques, Université \\ d'Abomey, Cotonou, Calavi, Benin \\ Correspondence: Akplo Tobi Moriaque, Laboratoire de Microbiologie des Sols et d'Ecologie Microbienne, \\ Faculté des Sciences Agronomiques, Université d'Abomey-Calavi-Université Nationale d'Agriculture, BP: 711, \\ Abomey, Calavi, Benin. E-mail: moriaqueakplo@gmail.com
}

Received: July 30, 2019 Accepted: August 29, $2019 \quad$ Online Published: October 15, 2019

doi:10.5539/jas.v11n17p110

URL: https://doi.org/10.5539/jas.v11n17p110

\begin{abstract}
Water erosion threatens large agricultural areas in Benin. This study dealing with the effect of personal household's attributes and field physical characteristics on erosion control practices was carried out in the watershed of Zou. A total of 390 farmers distributed in six were randomly sampled. Questionnaires, interview, focus group discussion and field observation were used as the main data collection technics. It allowed to collect sociodemographic and institutional characteristics and have a view on the effectiveness of the erosion control practices adoption. The data were analyzed using descriptive statistic and logistic regression. Ridging parallel to the slope (40.77\% in adoption); mulching (11.03\% in adoption); isohypse ridging (16.67\% in adoption) and no-tillage (8.46 in adoption) were inventoried as soil erosion control practices on the watershed. It appears that that the household's sociodemographic and institutional attributes and field physical characteristics significantly affected the adoption of the inventoried water erosion control practices. Sex, education, farmer's organization membership, landownerships, access to agricultural advice service, position of the field on the toposequence and presence of water stream significantly influenced the soil erosion control practices adopted on the watershed. The results of this study showing that set of factor sway farmers to adopt soil erosion control practices can help policy makers to upscale the adoption of the practices and soil scientists to orient their research programs on erosion control practices.
\end{abstract}

Keywords: modeling, adoption, soil erosion control practices, watershed, Republic of Benin

\section{Introduction}

Soil erosion is a major environmental and agricultural problem and affects worldwidly more than 10 million hectares per year (World Economic Forum, 2010). Some statistic showed that it has caused about $85 \%$ of the world land to be degraded and $17 \%$ of crop production to be reduced (Scherr \& Yadav, 1996). Africa hosts more than $45 \%$ of the total erosion affected people and soil lost by erosion concern about 5 to 6 million hectares of land each year (Assefa, 2009; FAO, 2002). In Benin, water erosion is a major process of soil degradation (Kouelo et al., 2015a). In many agroecological areas, erosion has leach the top soil (Assogba et al., 2017). Thus, Barthès et al. (2002) have shown that the different regions of Benin are sensitive to rain aggressiveness. Toko \& Sinsin (2008) and Avakoudjo et al. (2013) have found that northwestern part of Benin is marked by the phenomenon of massive land loss called "Donga". Azontondé et al. (2016) have showed that the agroecological zones 3 and 5 are affected by water erosion due to splash and runoff and gully erosion. In central Benin, water erosion is very recurrent due to the rains aggressiveness; non-sustainable agricultural practices (Igué et al., 2013); and geological material formed on the very waterproof peneplain (Adam \& Boko, 1993). For several years, soil erosion control strategies have been developed and tested by agricultural research and extended with farmers. Many soil erosion control practices were introduced in Benin since 1960. The most important are mulching, no- 
tillage, cover crop and stone terraces (Baba et al., 2016). However, it is noteworthy that these strategies are weakly adopted (Akpinfa et al., 2016). For the most part, they were developed in a top-down approach, without taking into account the native practices. The challenge is therefore to study traditional practices and the factors influencing their adoption. At African scale, many recent studies have been conducted to understand the drivers of adoption decisions of soil and water conservation (SWC) practices (Amsalu \& De Graaff, 2007; Knowler \& Bradshaw, 2007; Fikru, 2009; Abdulai \& Huffman, 2014; Ndiritu et al., 2014; Kouelo et al., 2015b). However, in Benin the factors affecting soil erosion control practices adoption are rarely studied. This exploratory study aims at assessing the sociodemographic and institutional determinants of Soil Erosion Control (SEC) practices adoption in the centre of Benin. Basing on findings of some authors (Ngondjeb et al., 2011; Asfaw \& Neka, 2017; Kpadonou et al., 2017; Mango et al., 2017), we made assumption that a set of factors may sway farmers to adopt soil erosion control practices.

\section{Materials and Methods}

\subsection{Description of the Study Area}

The studied watershed is drained by the rivers of Zou and is located between $7^{\circ} 05^{\prime}-7^{\circ} 42^{\prime}$ North and $2^{\circ} 04^{\prime}-2^{\circ} 24^{\prime}$ East (Figure 1). The rainfall pattern is bimodal in the two sites: long rain season (LR) lasting from March to Jully and short rain season (SR) from late September to November. The average annual rainfall is around $1200 \mathrm{~mm}$. The temperatures range from 22 to $24^{\circ} \mathrm{C}$ and 25 to $37^{\circ} \mathrm{C}$ for minima and maxima respectively. Eruptive rocks characterize the top area of the watershed whereas sedimentary series is localized in bottom (Faure and Volkoff 1998). A total of 9 soil units were mapped to the study area. Tropical ferruginous soils are the most represented in terms of area. According to Adomou (2005), vegetation is composed of moist semi-deciduous forests, galleries and clear forests and timbered savannahs. The human density is about 30 habitant $/ \mathrm{km}^{2}$ and the local socio-cultural groups are Fon (42\%); Mahi (45\%); Adja (10\%); Yoruba-Nago (3\%) (INSAE, 2016). Agriculture is the main activity and the major cropping system is rain fed maize-based.

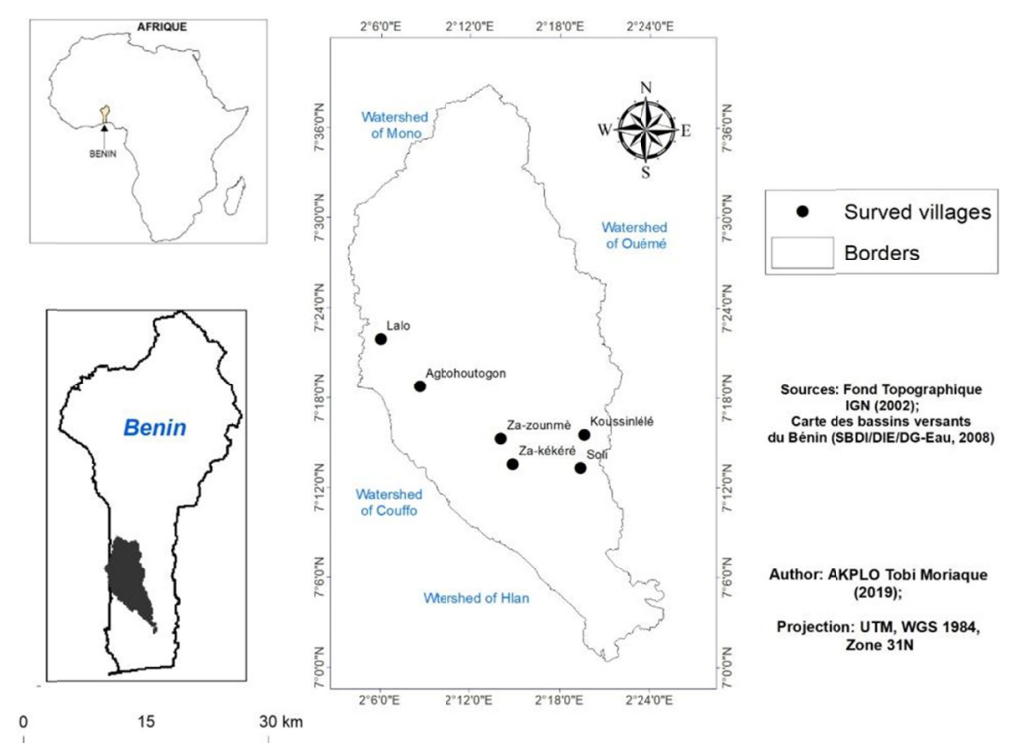

Figure 1. Study area

\subsection{Sampling}

Prospection has been done in prelude of the study on the watershed. The aim was to list villages in which water erosion is effective and have a general view on the adopted erosion control practices. Basing on the results of this preliminary step, six villages have been selected in three towns (Table 1) on the watershed. For the survey step, the sample size was (n) was obtained by the normal approximation of the binomial distribution of Dagnelie (1998):

$$
\mathrm{n}=\left[\left(\mathrm{U}_{1-\alpha / 2}\right)^{2} \times \mathrm{p}(1-\mathrm{p})\right] / \mathrm{d}^{2}
$$

where, $U_{1-\alpha / 2}=$ confidence level of $95 \%$ (typical value of 1.96 ); $d=$ margin of error of $5 \%$ (typical value of 0.05 ); $\mathrm{p}=$ proportion known or suspected in the parent population ( $\mathrm{p} \geq 1 / 10$ of population). We considered $\mathrm{p}=1 / 2$ of 
the parent population. For this study, 390 farmers were randomly sampled in 6 villages $(64.02 \approx 65$ farmers were selected per village) as described below.

Table 1. List of surveyed villages

\begin{tabular}{lll}
\hline Municipalities & Villages & Sampling size \\
\hline Djidja & Agbohoutogon & 65 \\
& Lalo & 65 \\
\hline Covè & Koussinlélé & 65 \\
& Soli & 65 \\
\hline Za-kpota & Za-zounmè & 65 \\
& Za-kékéré & 65 \\
\hline Total & & 390 \\
\hline
\end{tabular}

\subsection{Collection Tools and Data Collection}

Questionnaires, interview, focus group discussion and field observation were used as the main data collection technics. The questionnaire included both closed and opened questions. The questionnaire enabled to collect data from representative sample of farmers. Interview was conducted with key informants who were considered knowledgeable about the general situation of soil and water conservation practices. Field observation enabled to verify the effectiveness of the SEC practices adoption, visual indicators of erosion and the physical characteristics (position of the field on the toposequence, presence of water stream) of the farms. However, articles, thesis, annual reports and statistical data about the physical and socio-economic conditions of the study area were used for enhancing the information collected from informants and field observation.

\subsection{Analytical Approach}

\subsubsection{Descriptive Statistic}

Data are analysed using descriptive statistics and frequencies in SPSS 20. The Chi square test is conducted to statistically verify whether there is a dependency between soil erosion control practices and physical characteristic of the farms.

\subsubsection{Modelling of Determinants of Soil Erosion Control (SEC) Practices}

In the econometric literature, the most used models for analysing the influence of qualitative or quantitative variables on a dependent dichotomous variable are generally grouped in four types: i) models with linear probability; ii) logistics function (LOGIT); iii) functions with normal density (PROBIT) and iv) limited dependent variable models (Tobit) (Ngondjeb, 2011). For all of them, the objective is the modelling of an alternative $(\mathrm{Y}=1$ or $\mathrm{Y}=0)$ and thus to estimate the probability associated with the event $\mathrm{Y}=1$. But Tobit models are used in the case of limited dependent variables. LOGIT models are considered approximations of PROBIT models for simpler calculations. In this article, we have therefore chosen the Logit model to identify and analyse the factors determining the adoption of anti-erosion practices. Due to the fact that the dependent variable under consideration has four independent modalities, a multinomial logistic regression was used. Using this model, it was assumed that the adoption of an erosion control practice depends significantly on the socio-demographic, institutional characteristics of farm managers and the biophysical characteristics of farms. Non-adoption (NoPra) was considered as a reference variable. The dependent variables include soil erosion control practices adopted in studied area. The investigated practices are: Ridging parallel to the slope; isohypse ridging; mulching and no tillage.

Previous studies have related to decisions of adoption soil conservation strategies, including soil erosion control practices. Factors determining famers' decision are often ranged as sociodemographic, institutional of the household and biophysical characteristics of the farm (Amsalu \& Graaff, 2007; Mango et al., 2017; Asfaw \& Neka, 2017). In this study, the independent variables taken in account can be grouped into two categories: (i) the sociodemographic and institutional variables of households and (ii) the biophysical characteristics of farms (Table 2). The socio-demographic and institutional characteristics are: age of the household head, sex of the household head, the literacy status and the level of education household head, the access of the extension services, farmer's organization membership, the household size and land tenure. The influence of the chosen explicative variables on the adoption of Soil and Water Conservation (SWC) including Soil Erosion Control 
(SEC) practices is widely documented. Barungi and Manga (2011), Asfaw and Neka (2017), Ngondjeb et al. (2011), and Jara-Rojas et al. (2012) showed that the decision to adopt SEC practices depend positively at statistical significant level on the sex, the ownership of land, access to extension services and training and farmer's organization membership of household heads. Tiwari et al. (2008) reported that age of household heads negatively influenced at statistically significant level farmer's decision to adopt SEC practices. McDonald and Brown (2000) concluded that farmers rarely sustain the technical solutions offered by external interventions in the long term unless consideration is given to the biophysical and technical factors. Biophysical factors as slope were considered as determining of stone terraces adoption for soil and water conservation in an Ethiopian highland watershed by Amsalu and Graaff (2007).

Table 2. Independent variables chosen in this study

\begin{tabular}{lll}
\hline Variable & Description and variable measurement & Expected sign \\
\hline Sexhh & Sex of household head dummy $(1=$ male; $0=$ Female $)$ & Positive \\
Agehh & Age of household head (years $)$ & Negative \\
Literacyhh & Access of literacy program of the household head $(0=$ no; $1=$ yes $)$ & Positive \\
Educationhh & Number of years' formal education of household head & Positive \\
FMembershiphh & Household members belong to farmers organization $(0=$ no; $1=$ yes $)$ & Positive \\
Landowhh & Land ownership $(0=$ no; $1=$ yes $)$ & Positive/Negative \\
Hhsize & Number of active men of the household & Positive \\
Agricadvicehh & Access to agricultural advice $(0=$ no; $1=$ yes $)$ & Positive \\
Positionf & Position of the field on the toposequence $(0=$ down; $2=$ middle; $3=$ top $)$ & Positive/negative \\
Slopf & Steepness of the slope $(0=$ flat; $1=$ gentle; $2=$ moderate; $3=$ underlate & Positive/negative \\
Waterf & Presence of principal water stream or affluent $(0=$ no; $1=$ yes $)$ & Positive \\
\hline
\end{tabular}

\section{Results}

\subsection{Descriptive Statistics}

The descriptive statistics related to the selected household's attributes and the characteristics of the investigated farms are presented in Table 3. It was appeared that sampled informants are mostly male (61.54\%). The age's class most represented are 20-30 years-old and 30-40 years-old. Moreover, households with a number of active men between 0 and 5 were most considered in this study. As far as educational status is concerned, important part of sampled farmers is non-literate and do not has access to formal school. About eighty percent $(80 \%)$ of informants are not members of any farmer's organization, $61.03 \%$ are land owners, and about $14 \%$ have access to agricultural advice services. Concerning soil erosion control practices adoption, it is noteworthy in Table 3 that more than $70 \%$ of male informants; $60 \%$ of literate informants; $75.47 \%$ of informants who have access to advice service and $93.70 \%$ of informants who are land owner are adopters. Farms located at the top of the slope represent $61.54 \%$ of the farms surveyed in this study and $45.83 \%$ of them is adopter of at least one erosion control practice. $40 \%$ and $20.80 \%$ of the farmers whose fields are located at the middle slope and at the downslope adopt at are adopter and $59.03 \%$ of the fields located near a water stream are adopter. 
Table 3. Descriptive statistics and characterisation of adopters in the studied area $(n=390)$

\begin{tabular}{|c|c|c|c|}
\hline Characteristics & Modalities & $\%$ of sample & \% Adopters \\
\hline \multirow{2}{*}{ Sex } & Female & $150(38.46)$ & $119(22.08)$ \\
\hline & Male & $240(61.54)$ & $173(79.33)$ \\
\hline \multirow{2}{*}{ Literacy } & illiterate & $300(76.92)$ & $158(32.67)$ \\
\hline & literate & $90(23.08)$ & $54(60)$ \\
\hline \multirow{3}{*}{ Formal education level } & non instructed, & $249(63.85)$ & $74(29.72)$ \\
\hline & primary level & $134(34.36)$ & $110(82.08)$ \\
\hline & secondary level & $7(1.79)$ & $7(100)$ \\
\hline \multirow{2}{*}{ Access to advice service } & No & $337(86.41)$ & $152(45.10)$ \\
\hline & Yes & $53(13.59)$ & $40(75.47)$ \\
\hline \multirow{2}{*}{ Farmer's organization membership } & No & $313(80.26)$ & $230(73.48)$ \\
\hline & Yes & $77(19.74)$ & $62(80.51)$ \\
\hline \multirow{2}{*}{ Land ownership } & No & $152(38.07)$ & $69(45.39)$ \\
\hline & Yes & $238(61.03)$ & $223(93.70)$ \\
\hline \multirow{5}{*}{ Age } & 20-30 years-old & $119(30.51)$ & $80(67.22)$ \\
\hline & $30-40$ years-old & $124(31.79)$ & $98(79.03)$ \\
\hline & 40-50 years-old & $114(29.23)$ & $88(77.19)$ \\
\hline & 50-60 years-old & $9(2.31)$ & $5(55.56)$ \\
\hline & $>60$ years-old & $24(6.15)$ & $5(20.83)$ \\
\hline Minimum Age & & 20 & \\
\hline Mean Age & & $40 \pm 3$ & \\
\hline Maximum Age & & 70 & \\
\hline \multirow{3}{*}{ Number of active men } & $0-5$ & $159(40.77)$ & $95(59.75)$ \\
\hline & $5-10$ & $138(35.28)$ & $108(78.26)$ \\
\hline & $>10$ & $93(23.85)$ & $89(95.70)$ \\
\hline Minimum Active Men & & 1 & \\
\hline Mean Active Men & & $8 \pm 2$ & \\
\hline Maximum Active Men & & 30 & \\
\hline \multirow{3}{*}{ Position on the toposequence } & Top & $240(61.54)$ & $110(45.83)$ \\
\hline & Middle & $30(7.69)$ & $12(40.00)$ \\
\hline & Down & $120(30.77)$ & $25(20.80)$ \\
\hline \multirow{2}{*}{ Water stream } & No & $102(26.15)$ & $25(24.51)$ \\
\hline & Yes & $288(73.85)$ & $170(59.03)$ \\
\hline
\end{tabular}

\subsection{Visible Indicators of Water Erosion}

Six visual indicators of erosion were inventoried in the surveyed farms (Figure 2). They were: Rill (Figure 3A), Fall of crop (Figure 3B), Gully (Figure 3C), Ridges destruction (Figure 3D), Runoff (Figure 3E), and Naked root of crop (Figure 3F). But the visible witnesses of water erosion depend significantly on the situation of the field on the toposequence $\left(\chi^{2}=31.73, p=0.0015\right)$ and the proximity of the field of water stream $\left(\chi^{2}=91.32, p<0.0001\right)$. In the fields located at the top of the slope, the most visible indicators of erosion are the fall of the crops installed $(33.33 \%)$ and the destruction of the ridges $(26.19 \%)$. In the fields located in the middle, the most identified indicators are the fall of the crops $(40.65 \%)$ and the presence of gully (33.18\%). At Downslope, about $22 \%$ of the studied field do not have visible erosion indicators. But at this position of the toposequence, naked crop roots were the most observed (24.56\%). In more than $70 \%$ of the fields whichout main stream or affluent, no visible indicators of water erosion have been identified (Table 4). The most visible erosion indicator observed in the fields where there is main watercourse or a tributary, are the fall of culture (37.99\%); gully $(26.68 \%)$ and naked root of crop $(19.49 \%)$. 


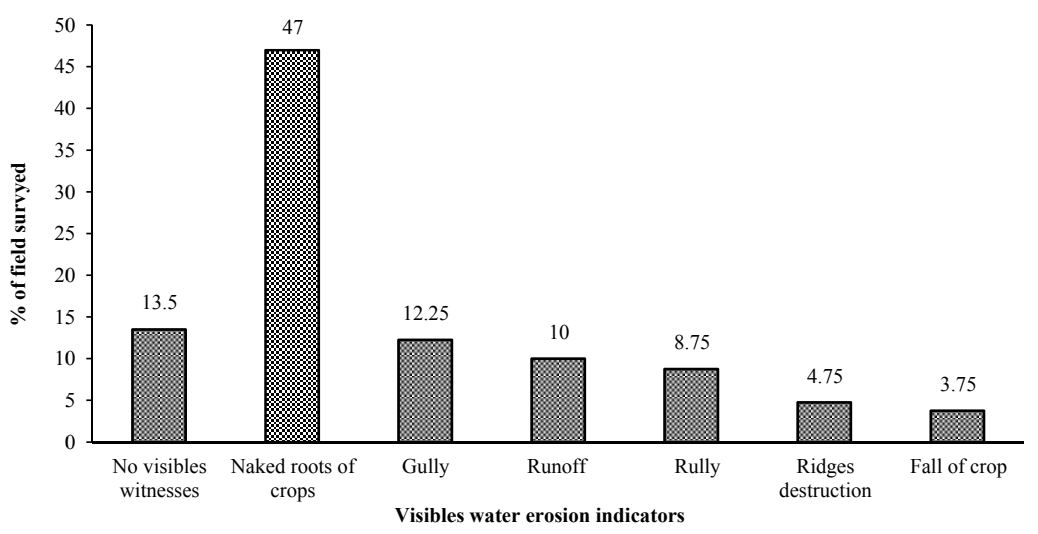

Figure 2. Percentage of water erosion indicators observed/watched on the watershed of Zou
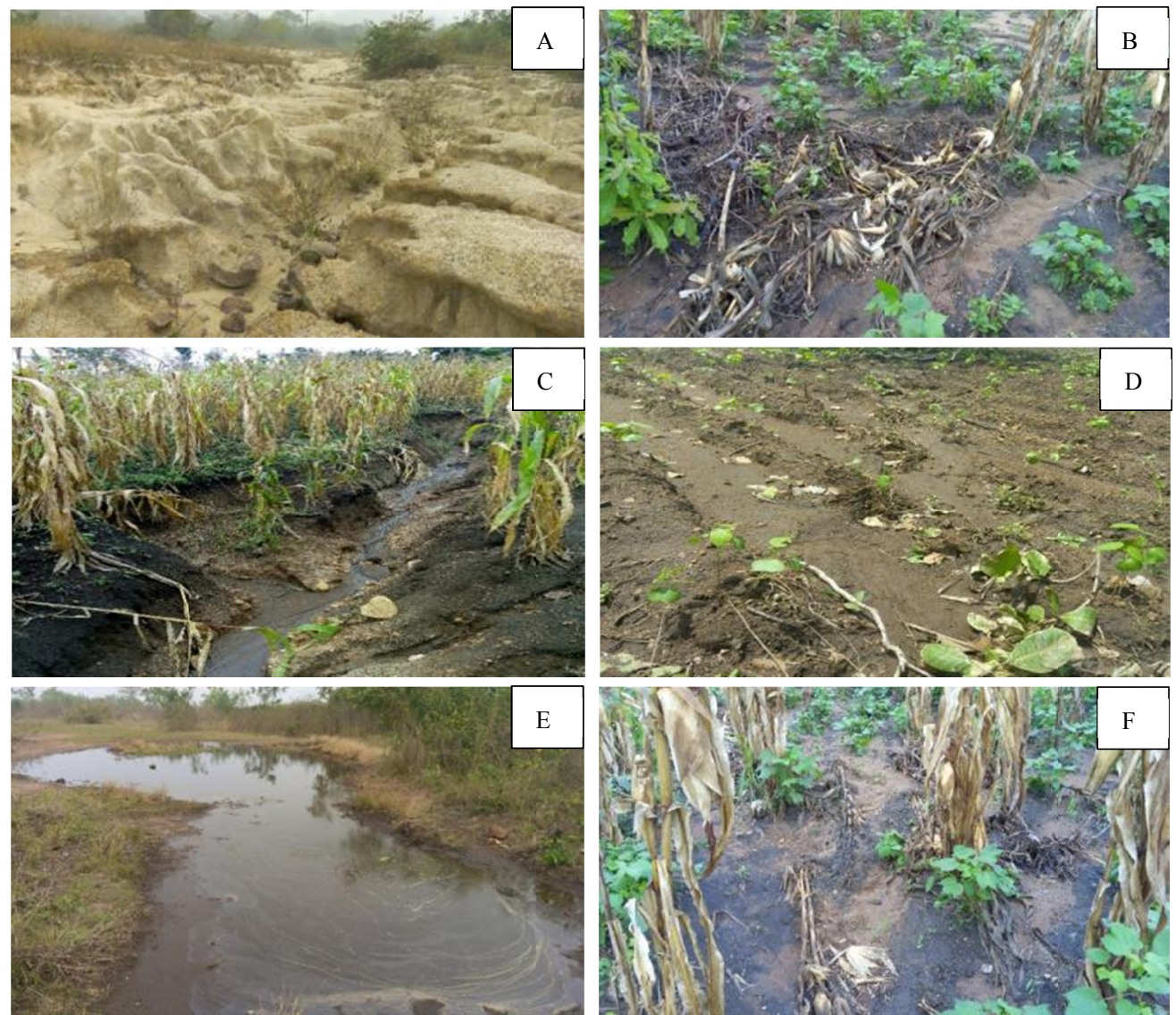

Figure 3. Soil erosion indicators observed: (A) Rill; (B) Fall of crop; (C) Gull; (D) Ridges destruction; (E) Runoff; (F) Naked root of crop

Table 4. Importance of soil erosion indicators according to field's physical characteristics

\begin{tabular}{|c|c|c|c|c|c|c|c|c|c|}
\hline & Fall of crop & Rilly & Gully & Ridges destruction & Naked root of crop & Runoff & No visible indicator & $\mathrm{Khi}^{2}$ & $\mathrm{p}$-value \\
\hline \multicolumn{10}{|c|}{ Position of the field on the toposequence } \\
\hline Top & 33.33 & 18.15 & 14.58 & 2.98 & 2.38 & 2.38 & 26.19 & \multirow{3}{*}{31.73} & \multirow{3}{*}{0.0015} \\
\hline Mid-slope & 40.65 & 33.18 & 10.75 & 2.34 & 3.74 & 2.34 & 7.01 & & \\
\hline Down & 24.56 & 16.67 & 18.42 & 8.77 & 5.26 & 4.39 & 21.93 & & \\
\hline \multicolumn{10}{|c|}{ Presence of principal water stream or affluent } \\
\hline Water stream & 37.99 & 26.68 & 1.32 & 5.53 & 19.49 & 2.11 & 6.89 & \multirow{2}{*}{91.32} & \multirow{2}{*}{$<0,0001$} \\
\hline No water stream & 16.48 & 5.44 & 2.57 & 2.94 & 1.53 & 1.00 & 70.04 & & \\
\hline
\end{tabular}




\subsection{Soil Erosion Control Practices Intensity of Adoption}

The specific adoption intensity of the SEC practices is presented in Table 4. It can be observed that adoption intensity ranged from $8 \%$ (no-tillage) to $41 \%$ (Ridging parallel to the slope). The cumulative intensity of adoption of the four practices inventoried is about $77 \%$ used at least of one soil erosion practices. However, no-tillage and mulching are the least adopted practices. The SEC inventoried can be grouped into two broad categories: (i) practices acting on land cover and (ii) practices affecting tillage. The first category includes mulching (Figure 4A). The second category includes isohypse ridging (Figure 4B); Ridging parallel to the slope (Figure 4C) and no-tillage (Figure 4D). The Ridging parallel to the slope is a type of tillage whose seedling lines are oriented parallel to slope direction. Isohypse ridging designates a type of ridging made following the contour lines. Mulching is one of the most important soil and water conservation technics. In the study area, the mulch is made of crop residues and weeds mown during soil preparation. The no-tillage practice consists in direct sowing without any actual soil work. The seedling poop are made with a machete or hoe on a depth proportional to seed size.
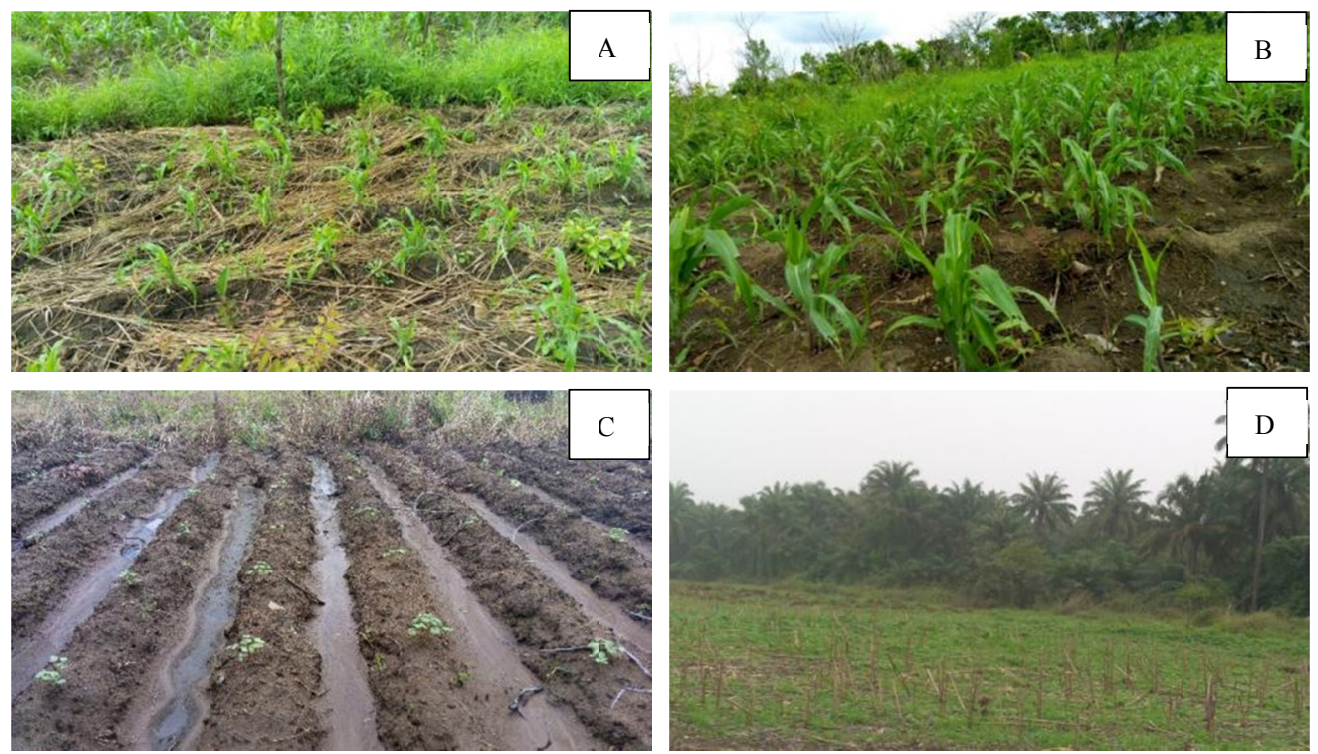

Figure 4. Inventoried soil erosion control practices: (A) Mulch made with couch-grass; (B) Isohypse ridging; (C) Ridging made following the slope; (D) No-tillage practice

Table 5. Intensity of the adoption of SEC practices

\begin{tabular}{lll}
\hline & N & Adoption intensity (\%) \\
\hline No adopters & 90 & 23.08 \\
Ridging parallel the slope & 159 & 40.77 \\
Isohypse Ridging & 65 & 16.67 \\
Mulching & 43 & 11.03 \\
No tillage & 33 & 8.46 \\
Total & 390 & 100.00 \\
\hline
\end{tabular}

\subsection{Determinants for Water Erosion Control Practice}

The parameters of multinomial Logit are reported in Table 6. As shown by the "Testing Global Null Hypothesis: BETA $=0$ " performed by a Wald test $\left(\mathrm{Chi}^{2}(56)=143.18, \mathrm{p}>\mathrm{Chi}^{2}<.0001\right)$, the model fits the data very well, meaning that the null hypothesis that all regression coefficients are jointly equal to zero is rejected. In addition, the likelihood ratio test $\left(\mathrm{Chi}^{2}(56)=417.98, \mathrm{p}>\mathrm{Chi}^{2}<.0001\right)$ of the null hypothesis that covariance of the error terms across equations are not correlated is also rejected. Deviance $\left(\mathrm{Chi}^{2}(1376)=622.49, \mathrm{p}>\mathrm{Chi}^{2}=1.000\right)$ and Pearson Goodness-of-Fit Statistics $\left(\mathrm{Chi}^{2}(1376)=1487.62, \mathrm{p}>\mathrm{Chi}^{2}=0.719\right)$ indicate no lack of fit in the model. Concerning to the predictive efficiency, the McFadden' $\mathrm{R}^{2}$ indicate that the model explains $69 \%$ of the total 390 
sampled household heads included in the model correctly predicted the adoption of water erosion practices. Type 3 tests show that most of the explicative variable are important for the model. Indeed, the effects of some explicative variable, such as sex of household head, Access of literacy program of the household, Education level of the household head, Household member belong to farmer's organization, Land ownership, Size of household, Position of the farm on the toposequence, Steepness of the slope and Presence of major watercouses or affluent are also significant.

Table 6. Accuracy parameters of the logistic model

\begin{tabular}{|c|c|c|c|}
\hline Criterion & Intercept Only & & Intercept and Covariates \\
\hline AIC & 1081.02 & & 772.35 \\
\hline $\mathrm{SC}$ & 1096.68 & & 1038.65 \\
\hline$-2 \log \mathrm{L}$ & 1073.02 & & 636.352 \\
\hline \multicolumn{4}{|c|}{ Testing Global Null Hypothesis: BETA =0 } \\
\hline Test & Chi-Square & DF & Pr>ChiSq \\
\hline Likelihood Ratio & 417.98 & 56 & $<.0001$ \\
\hline Score & 356.69 & 56 & $<.0001$ \\
\hline Wald & 143.10 & 56 & $<.0001$ \\
\hline \multicolumn{4}{|l|}{ Like-R $^{2}$} \\
\hline R-Square & 0.6759 & & \\
\hline Max-rescaled R-Square & 0.7156 & & \\
\hline \multicolumn{4}{|c|}{ Deviance and Pearson Goodness-of-Fit Statistics } \\
\hline Test & Chi-Square & DF & Pr>ChiSq \\
\hline Pearson & 1487.623 & 1376 & 0.719 \\
\hline Deviance & 622.489 & 1376 & 1.000 \\
\hline
\end{tabular}

Finding highlight that household's age positively affected adoption of Ridging parallel to the slope, no tillage, while the effect was negative on the adoption of Isohypse Ridging (Table 7). The odds of a farmer unexpectedly adopting Ridging parallel to the slope and no tillage were found to increase with the age of the household head, respectively by a factor of 2.83 and 1.06. However, Mulching and Isohypse Ridging adoption were found to decrease with the household head 'age respectively by factor of 0.13 and 0.36 . The literacy of household head significantly influenced their decision to adopt Isohypse Ridging. The Wald test (Wald Chi-sq = 11.20; p-value = 0.0008) confirm this effect and the odd ration showed that literate farmer more adopts Isohypse Ridging by a factor of 17.91 compared to illiterate farmer. Sex significantly and positively determined the household head decision to adopt one least soil erosion control practices. The odds ratio displayed that men are more adopters by a factor of 5.89; 6.07; 11.52 and 4.65 compared with women respectively for Ridging parallel to the slope; Isohypse ridging; Mulching and no-tillage. The number of years of formal education positively correlated with the adoption of Isohypse Ridging; mulching and no-tillage but negatively correlated with adoption Ridging parallel to the slope. The values of the Wald test show that this correlation is significant for Isohypse Ridging (Wald Chi-sq $=2.88$; p-value $=0.0894)$; mulching (Wald Chi-sq $=4.77$; $\mathrm{p}$-value $=0.0289$ ) and Ridging parallel to the slope (Wald Chi-sq $=5.97 ; \mathrm{p}$-value $=0.0145$ ). The odds ratio has showed that one-years increase of formal education for the household head is associated with an increasing of adoption of Ridging by a factor of 0.75 and the adoption of mulching by a factor of 1.54; while one-years increase of formal education for the household head is associated with a decreasing of Ridging parallel to the slope by a factor of 1.52. We found a positive significant correlation of farmer's organization membership with whole the investigated soil erosion control practices. The odd ratio displayed that compared to the farmers who are not organization members, those who are organization members of the household head adopts of Ridging parallel to the slope by $95 \%$; adoption of Isohypse Ridging by $84 \%$; adoption of mulching by $27 \%$ and no-tillage adoption by $64 \%$. The results showed that land ownership is significant determinant of the erosion control practices adopted. It was found out that land owners are more adopters of Ridging parallel to the slope; Isohypse Ridging Mulching and No tillage. The access to agricultural advice service significantly influenced soil erosion practice adoption. The relationship of these variables with adoption is positive. As far as the influence of physical characteristics of the farms are concerned, the model revealed that in the farms localized at the middle of the slope, isohypse ridging and mulching are significantly adopted by a factor of 4.17 and 5.80 respectively in comparison with the farms localized on the top the slope. In the farms localized at downslope, ridging parallel to the slope, isohypse ridging, mulching and No tillage practices are 
significantly adopted. The presence of a main water stream or a tributary significantly influenced the decision to adopt an anti-erosion practice. In fact, the presence of water stream increases positively the adoption of ridging parallel to the slope, isohypse ridging, mulching and No tillage by $9.83 ; 19.86 ; 17.61$ and 5.28 compared with non-presence of water stream.

Table 7. Multinomial Logit regression results for adoption of the water control erosion practices in the Zou watershed $(*$ for $\mathrm{p}$-value significant at $10 \% ; * *$ for $\mathrm{p}$-value significant at $5 \% ; * * *$ for $\mathrm{p}$-value significant at $1 \%$ ). mr denote the reference modalities

\begin{tabular}{|c|c|c|c|c|c|c|c|c|c|c|c|c|}
\hline \multirow[b]{2}{*}{ Variable } & \multicolumn{3}{|c|}{ Ridging parallel the slope } & \multicolumn{3}{|c|}{ Isohypse Ridging } & \multicolumn{3}{|c|}{ Mulching } & \multicolumn{3}{|c|}{ No tillage } \\
\hline & Estimate & $\begin{array}{l}\text { Wald } \\
\text { Chi-Square }\end{array}$ & $\begin{array}{l}\text { Odd } \\
\text { ratio }\end{array}$ & Estimate & $\begin{array}{l}\text { Wald } \\
\text { Chi-Square }\end{array}$ & $\begin{array}{l}\text { Odd } \\
\text { ratio }\end{array}$ & Estimate & $\begin{array}{l}\text { Wald } \\
\text { Chi-Square }\end{array}$ & $\begin{array}{l}\text { Odd } \\
\text { ratio }\end{array}$ & Estimate & $\begin{array}{l}\text { Wald } \\
\text { Chi-Square }\end{array}$ & $\begin{array}{l}\text { Odd } \\
\text { ratio }\end{array}$ \\
\hline Intercept & -15.87 & $25.52^{* * * *}$ & 0.00 & -16.15 & $16.20^{* * * *}$ & 0.00 & -17.29 & $26.61^{* * * *}$ & 0.00 & -19.48 & $22.95^{* * *}$ & 0.00 \\
\hline Agehh & 1.04 & $5.96^{*}$ & 2.83 & -1.02 & $4.35^{* *}$ & 0.36 & -2.03 & $1.57^{*}$ & 0.13 & 0.06 & $4.71^{*}$ & 1.06 \\
\hline Hhsize & 0.33 & $7.12^{* *}$ & 1.39 & 0.26 & $4.09^{* * *}$ & 1.29 & 0.40 & $10.14^{* *}$ & 1.49 & 0.18 & 1.85 & 1.20 \\
\hline$[\mathrm{Sexhh}=\mathrm{F}]$ & $\mathrm{mr}$ & & & & & & & & & & & \\
\hline$[\mathrm{Sexhh}=\mathrm{M}]$ & 1.14 & 2.95 & 3.13 & 1.78 & $5.83^{*}$ & 5.93 & 0.92 & 1.51 & 2.51 & 1.86 & $4.75^{*}$ & 6.4 \\
\hline$[$ Literacyhh $=0]$ & $\mathrm{mr}$ & & & & & & & & & & & \\
\hline$[$ Literacyhh=1] & -1.03 & 1.30 & 0.36 & 2.89 & $11.20^{*}$ & 17.91 & 0.14 & 0.02 & 1.15 & -1.34 & 1.52 & 0.26 \\
\hline [Educationhh] & -0.42 & $5.97^{* *}$ & 1.52 & 0.29 & $2.88^{* * *}$ & 0.75 & 0.44 & $4.77^{* *}$ & 1.54 & 0.09 & 0.24 & 1.06 \\
\hline$[$ FMembershiphh $=0]$ & $\mathrm{mr}$ & & & & & & & & & & & \\
\hline [FMembershiphh=1] & 5.56 & $7.46^{* *}$ & 259.95 & 4.27 & 1.82 & 71.84 & 7.80 & $13.39^{* * * *}$ & 2444.27 & 6.56 & $5.42^{*}$ & 705.64 \\
\hline$[$ Landwhh $=0]$ & $\mathrm{mr}$ & & & & & & & & & & & \\
\hline [Landwhh=1] & 4.14 & $30.65^{* * *}$ & 62.70 & 4.39 & $26.63^{* * *}$ & 80.64 & 2.40 & $8.58^{* *}$ & 11.01 & 5.55 & $19.69^{* * *}$ & 256.34 \\
\hline$[$ Agricadvicehh=0] & $\mathrm{mr}$ & & & & & & & & & & & \\
\hline [Agricadvicehh=1] & 6.90 & $10.75^{* *}$ & 990.39 & 6.19 & 3.74 & 487.85 & 7.52 & $11.75^{* * *}$ & 1845.49 & 7.41 & $6.66^{* * *}$ & 1660.21 \\
\hline$[\mathrm{Posf}=0]$ & $\mathrm{mr}$ & & & & & & & & & & & \\
\hline$[\mathrm{Posf}=1]$ & 1.34 & $3.54^{*}$ & 3.83 & 1.44 & 3.51 & 4.20 & 1.58 & $3.83^{*}$ & 4.85 & 0.76 & 0.81 & 2.14 \\
\hline$[\mathrm{Pos} f=2]$ & 3.18 & $7.03^{* *}$ & 24.09 & 4.00 & $10.47^{* *}$ & 54.64 & 2.36 & $3.29^{*}$ & 10.60 & 2.19 & 2.61 & 8.91 \\
\hline [Slopef=0] & $\mathrm{mr}$ & & & & & & & & & & & \\
\hline [Slopef $=1]$ & 4.91 & $28.24^{* * * *}$ & 135.25 & 4.63 & $21.98^{* * *}$ & 102.66 & 5.70 & $32.42^{* * * *}$ & 297.61 & 4.45 & $17.60^{* * *}$ & 85.82 \\
\hline$[$ Slopef $=2]$ & 3.35 & $14.47^{* * *}$ & 28.39 & 3.99 & $18.91^{* * *}$ & 53.84 & 3.98 & $16.62^{* * *}$ & 53.26 & 4.16 & $16.52^{* * *}$ & 64.11 \\
\hline$[$ Slopef $=3]$ & 5.87 & $10.71^{* * *}$ & 355.06 & 4.56 & $5.64^{* *}$ & 95.55 & 4.46 & $4.82^{*}$ & 86.81 & 6.29 & $11.12^{* * *}$ & 536.73 \\
\hline$[$ Water $=0]$ & $\mathrm{mr}$ & & & & & & & & & & & \\
\hline [Water $=1]$ & 2.38 & $10.59^{* * *}$ & 10.86 & 3.08 & $15.20^{* *}$ & 21.74 & 2.96 & $13.73^{* * *}$ & 19.29 & 1.77 & $4.31^{* * *}$ & 5.89 \\
\hline
\end{tabular}

\section{Discussion}

\subsection{Erosion Control Practices Adoption}

Erosion, runoff and nutrient loss constitute a tripling of phenomena that threaten the sustainability of agricultural production systems, especially in developing countries. In many rural areas, local people adopt many ancestral and / or popular practices for erosion control. On the watershed of Zou, four practices have been identified. Ridging parallel to the slope and Isohypse Ridging were fund to be more adopted. The SEC practices inventoried can be grouped into two broad categories: (i) practices affecting tillage and (ii) practices acting on land cover. The first category concerns Ridging parallel to the slope, isohypse ridging and no-tillage. The second category concerns mulching. These practices are widely known as SWC practices (Abdulai \& Huffman, 2014; Akplo et al., 2017; Kpadonou et al., 2017). The Ridging parallel to the slope is a type of tillage whose seedling lines are oriented parallel to the direction of the slope. Isohypse ridging designates a type of ridging made according the contour lines. Mulching is one of the most important soil and water conservation technics. In the study area, the mulch is made of crop residues and weeds mown during soil preparation. For some authors, residue cover protects soil from degradation caused by raindrops (Akplo et al., 2017). With the removal of vegetation cover and fallow, inherent fertility is drastically reduced and accelerated erosion (Nyakatawa et al., 2001; Isikwue, 2005; Mazarei \& Ahangar, 2013). Peigné et al. (2007) have reported that conservation tillage covers a range of practices which conserve soil moisture and reduce soil erosion by maintaining a minimum of $30 \%$ of the soil surface covered by residue after drilling. No-tillage practice consists in direct sowing. The seedling poop is made with a machete or hoe on a depth proportional to the size of the seed. No-tillage practices are wildly considered to conservation tillage (Labreuche et al., 2007). Reducing the intensity of soil tillage decreases energy 
consumption and the emission of carbon dioxide, while increasing carbon sequestration and soil stability (Holland, 2004).

\subsection{Determinants for Water Erosion Control Practice}

It has longtime been argued that farmers only agree to adopt new or old technology when they find economic interest in it (Kabunga et al., 2012). But other non-direct economic factors could motivate the decision of adoption. The findings highlight that adoption of at least one soil erosion control strategy is significantly influenced by the household's age. Farmers adopting Ridging parallel to the slope and no tillage were found to increase with the age of the household head, respectively by a factor of 2.83 and 1.06 and mulching and isohypse ridging adoption were found to decrease with the household head's age respectively by factor of 0.13 and 0.36 . In other words, the older people adopt Ridging parallel to the slope and no tillage and the younger ones adopt more isohypse ridging and mulching. These adoption preferences can be explained, on the one hand, by the fact that older people are less able to provide the physical effort required to adopt certain practices than younger ones who can provide physical effort to pick up straws, crop residues and use them as mulch and also to do ridging parallel to the slope. The positive influence of age has been demonstrated by Mango et al. (2017) and Fikru (2009). However, Bekele and Drake (2003), Tiwari et al. (2008), and Ngondjeb et al. (2011) have found out that the household's age is negatively correlated with the soil erosion practices adoption. Sex significantly and positively influenced the household head decision to adopt one least soil erosion control practices. This is explained by the fact that the most of the practices require physical effort and additional work on the part of the adopter. Women are more charged to the housework and housekeeping (Asfaw \& Neka, 2017). Similar results were obtained by Aberha (2008) and Krishna et al. (2008) who have shown that men adopt more SWC including SEC practices, compared to women. The influence of the household active men size was not significant for the adoption of SEC practices. These results are consistent with those obtained by Mango et al. (2017) and those of Amsalu and De Graaff (2007) who conclude in studies in South Africa and Ethiopia that household size does not influence the decision of whether or not to adopt a practice of soil and water conservation including erosion control practices. Contrary to our findings, Bekele and Drake (2003) showed a significantly negative relationship between household size and adoption of conservation practices. The adoption of isohypse ridging as SEC practices is significantly influenced by literacy and the literate household heads are more adopters. The number of years of formal education also increase farmer's decision to adopt isohypse ridging; mulching and no tillage but negatively correlated with ridging parallel to the slope. These results highlight that literacy and education are keys pillars in SEC practices adoption. Such finding has been made by Brett (2004), and Adesina (2000). In addition, the preferential adoption of effective control practices (isohypse ridging, mulching and no-tillage) by the literate and those with an advanced level of education testifies to the fact that these practices require a technological floor that access to education allowed them to have. We found a positive significant correlation of farmer's organization membership with whole the studied soil erosion control practices. This observation justifies the fact that within farmers' organizations, producers exchange their own experiences with each other and are well informed about various technological innovations. Through technical supervision, they benefit from various trainings by technical extension agents and various projects (ProSol in example). Nyangena and Juma (2014), and Bandiera and Rasul (2006) attributed a strong adoption of soil conservation and anti-erosion practices to membership of a social network and access to the technical support of farmers. Land ownership had a positive impact on the adoption of ridging parallel to the slope; Ridging across the slope Mulching and No tillage, suggesting that farmers are more likely to adopt these practices on owned plots. Kpadonou et al. (2017) had supposed that this can be explained by the Marshallian inefficiency hypothesis where input use by the tenant on rented or borrowed land is lower or less efficient than on owned land. As far as the influence of physical characteristics was concerned, the findings revealed that on the farms localized at middle of the slope, isohypse ridging and mulching were the most adopted while at downslope, the adopted practices were ridging parallel to the slope, isohypse ridging, mulching and no-tillage. This indicates that at mid-slope and at the bottom of the slope, runoff is concentrated and erosion is more obvious. This leads farmers to resort to erosion control practices. The importance of the slope in the erosive phenomenon is widely recognized (Sadiki et al., 2005; El Garouani et al., 2007; Togbé, 2018). The presence of watercourses increases positively the adoption of at least one inventoried practices. This means that in the fields next to a watercourse, there is an emergency or need to take anti-erosion measures. In fact, the runoff flows to the watercourse, which leads farmers to control measures. The isohypse ridging slows down and sometimes cancels the flow of water. Mulch shields raindrops, preventing the detachment of soil particles. No-tillage avoids the loosening of clods of earth and greatly limits their training with runoff water. 


\section{Conclusion and Policy Implications}

The objective of this study is to determine the factors influencing the adoption of different water erosion control practices on the watershed of Zou. Four Soil Erosion Control practices were inventoried. We found that overall, $67 \%$ of the studied household adopted at least of one of the inventoried SEC practices. However, specific adoption rates are still very low for no-tillage and mulching. To provide a more comprehensive understanding of the challenges around the adoption of these practices, we used a multinominal logit. The findings showed that sex, age, land ownership, educational status, membership farmer's organization, access to agricultural advice service significantly determine the water erosion control practice adopted. Policymakers need thus (a) to target practices with lower adoption rates and provide farmers with further incentives towards the intensification of their use; (b) to includ water erosion control practices in the study area should take into account these factors and (c) to encourage the access to advice service, farmers network, literacy and training of farmers in particular to the young farmers as they play a key role in the adoption process of SEC practices as major labor suppliers within the farm.

\section{References}

Abdulai, A., \& Huffman, W. (2014). The adoption and impact of soil and water conservation technology: an endogenous switching regression application. Land Economy, 90(1), 26-43. https://doi.org/10.3368/ le. 90.1 .26

Aberha, E. T. (2008). Erosion and soil and water conservation group and environmental policy group. Continue use of soil and water conservation practices: A case study in Tulla District, Ethiopia (p. 57, Dissertation of MSc Degree, Wageningen University, Netherlands).

Adam, S., \& Boko, M. (1993). Le Bénin Les éditions du Flamboyant. EDICEF, Cotonou.

Adesina, A. A., Mbila, D., Nkamleu, G. B., \& Endamana, D. (2000). Economic analysis of the determinants of adoption of alley farming by farmers in the forest zone of southwest Cameroon. Agricculture, Ecosystems \& Environment, 80, 255-265. https://doi.org/10.1016/S0167-8809(00)00152-3

Adomou, A. C. (2005). Vegetation patterns and environmental gradients in Benin: Implications for biogeography and conservation (Doctoral dissertation, Wageningen University, Wageningen).

Akpinfa, E., Assogba, G.-C., \& Gouwakinnou, G. (2016). Analyse des projets de Gestion Durable des Terres (GDT) au Bénin (Report final, Bénin).

Akplo, T. M., Kouelo Alladassi, F., Houngnandan, P., Benmansour, M., Rabesiranana, N., Mabit, L., ... Alohoutade, F. M. (2017). Effect of tillage and mulching on soil water erosion in Linsinlin watershed, Centre of Benin. Journal of Experimental Biology and Agricultural Sciences, 5(4), 515-524. https://doi.org/ 10.18006/2017.5(4).515.524

Amsalu, A., \& De Graaff, J. (2007). Determinants of adoption and continued use of stone terraces for soil and water conservation in an Ethiopian highland watershed. Ecological Economics, 61(2), 294-302. https://doi.org/10.1016/j.ecolecon.2006.01.014

Asfaw, D., \& Neka, M. (2017). Factors affecting adoption of soil and water conservation practices: The case of Wereillu Woreda (District), South Wollo Zone, Amhara Region, Ethiopia. International Soil and Water Conservation Research, 5, 273-279. https://doi.org/10.1016/j.iswcr.2017.10.002

Assefa, D. (2009). Assessment of upland erosion processes and farmer's perception of land conservation in Debre Mewi watershed, near Lake Tana, Ethiopia (Master of Science dissertation, Cornell University, United States).

Assogba, S. C. G., Akpinfa, E., Gouwakinnou, G., \& Larissa, S. (2017). La Gestion Durable des Terres: Analyse d'expériences de projets de développement agricole au Bénin (Rapport de Synthèse, p. 32).

Avakoudjo, J., Kindomihou, V., Akponikpé, P. I., Thiombiano, A., \& Sinsin, B. (2013). Essences végétales et techniques de restauration des zones d'érosion (dongas) du Parc W et de sa périphérie à Karimama (Nord-Bénin). Journal of Applied Biosciences, 69, 5496-5509. https://doi.org/10.4314/jab.v69i0.95075

Azontondé, H. A., Igué, A. M., \& Dagbénonbakin, G. (2016). La carte de fertilité des sols du Bénin par zone agro-écologique du Bénin (Report final, p. 139).

Baba, C. A. K., Stiem, L., \& Lanouette, P. (2016). Expériences en Gestion Durable des Terres au Bénin: Quelles Leçons Tirer Pour les Orientations Futures? Rapport d'atelier, IASS Working Paper. 
Bandiera, O., \& Rasul, I. (2006). Social networks and technology adoption in northern Mozambique. The Economic Journal, 116(514), 869-902. https://doi.org/10.1111/j.1468-0297.2006.01115.X

Barthès, B., \& Roose, E. (2002). Aggregate stability as an indicator of soil susceptibility to runoff and erosion; validation at several levels. Catena, 47(2), 133-149. https://doi.org/10.1016/S0341-8162(01)00180-1

Barungi, M., \& Maonga, B. B. (2011). Adoption of soil management technologies by smallholder farmers in central and southern Malawi. Journal of Sustainable Development in Africa, 13(3), 28-38.

Bekele, W., \& Drake, L. (2003). Soil and water conservation decision behavior of subsistence farmers in the Eastern Highlands of Ethiopia: A case study of the Hunde-Lafto area. Ecological Economics, 46(3), 437-451. https://doi.org/10.1016/S0921-8009(03)00166-6

Brett, C. (2004). Farm level adoption decisions of soil water management technologies in semi-arid Eastern Kenya. 48th Annu. Conf. Australian Agricultural and Resource Economics Society, 11-13 February, 2004, Melbourne, Australian.

Dagnelie, P. (1998). Statistiques théoriques et appliquées (p. 517). Brussels: De Boeck.

FAO. (2002). Reducing poverty and hunger: the critical role offinancing for food, agriculture, and rural development. Paper presented at International Conference on Financing for Development, Monterrey, Mexico.

Faure, P., \& Volkoff, B. (1998). Some factors affecting regional differentiation of the soils in the Republic of Benin (West Africa). Catena, 32(3-4), 281-306. https://doi.org/10.1016/S0341-8162(98)00038-1

Fikru, A. (2009). Assessment of adoption of soil and water conservation practice in Koga watershed, highlands of Ethiopia (Master dissertation, Cornell University, USA).

Gujarati, D. N. (2009). Basic econometrics. Tata McGraw-Hill Education, New Delhi.

Holland, J. M. (2004). The environmental consequences of adopting conservation tillage in Europe: reviewing the evidence. Agricultural Ecosystems and Environment, 103, 1-25. https://doi.org/10.1016/j.agee. 2003.12 .018

Igué, A. M., Saidou, A., Adjanohoun, A., Ezui, G., Attiogbé, P., Kpagbin, G., ... Sogbedji, J. M. (2013). Evaluation de la fertilité des sols au sud et centre du Bénin. Bulletin de la Recherche Agronomique du Bénin, Numéro Spécial Fertilité du Maïs (p. 23).

INSAE (Institut National de la Statistique et de l'Analyse Economique). (2016). Effectifs de la population des villages et quartiers de ville du Bénin (RGPH-4, 2013) (Report final, p. 85).

Isikwue, M. O. (2005). Influence of nutrients and sediment loads from two rivers in Benue State on crop production (Doctoral dissertation, University of Nigeria, Nsukka).

Jara-Rojas, R., Bravo-Ureta, B., \& Diaz, J. (2012). Adoption of water conservation practices: A socio-economic analysis of small scale farmers in Central Chile. Agricultural Systems, 110, 54-62. https://doi.org/ 10.1016/j.agsy.2012.03.008

Knowler, D., \& Bradshaw, B. (2007). Farmers' adoption of conservation agriculture: A review and synthesis of recent research. Food Policy, 32(1), 25-48. https://doi.org/10.1016/j.foodpol.2006.01.003

Kouelo Alladassi, F., Houngnandan, P., Azontondé, H. A., Benmansour, M., Rabesiranana, N., \& Mabit, L. (2015a). Assessment of the level of soil degradation in three watersheds affected by intensive farming practices in Benin. Journal of Experimental Biology and Agricultural Sciences, 3(6), 529-540.

Kouelo Alladassi, F., Houngnandan, P., Azontondé, H. A., Dedehouanou, H., \& Gangnon, S. O. A. (2015b). Farmers' Perceptions on Soil Degradation and Their Socioeconomic Determinants in Three Watersheds of Southern Benin. Journal of Biology, Agriculture and Healthcare, 5(22), 29-39. https://doi.org/10.18006/ 2015.3(6).529.540

Kpadonou, R. A. B., Owiyob, T., Barbie, B., Dentona, F., Rutabingwa, F., \& Kiema, A. (2017). Advancing climate-smart-agriculture in developing drylands: Joint analysis of the adoption of multiple on-farm soil and water conservation technologies in West African Sahel. Land Use Policy, 61, 196-207. https://doi.org/ 10.1016/j.landusepol.2016.10.050

Krishna, R., Tiwari Bishal, K., Sitaula, I. L., Nyborg Giridhari, P., \& Paudel, S. (2008). Determinants of farmers' adoption of improved soil conservation technology in a middle mountain watershed of Central Nepal. Environmental Management, 42, 833-846. https://doi.org/10.1007/s00267-008-9137-z 
Labreuche, J., Le Souder, C., Castillon, P., Ouvry, J. F., Real, B., Germon, J. C., \& de Tourdonnet, S. (2007). Evaluation des impacts environnementaux des Techniques Culturales Sans Labour en France (p. 400). ADEME-ARVALIS Institut du Végétal-INRA-APCAAREAS-ITB-CETIOMIFVV. Retrieved June 23, 2017, from http://www2.ademe.fr/servlet/getDoc?cid=96\&m=3\&id=51256\&p1=00\&p2=11\&ref=17597

Mango, N., Makate, C., Tamene, L., Mponela, P., \& Ndengu, G. (2017). Awareness and adoption of land, soil and water conservation practices in the Chinyanja Triangle, Southern Africa. International Soil and Water Conservation Research, 5, 122-129. https://doi.org/10.1016/j.iswcr.2017.04.003

Mazarei, M., \& Ahangar, A. G. (2013). The Effects of Tillage and Geographic Factors on Soil Erosion: A Review. International Journal of Agriculture and Crop Sciences, 6, 1-024.

Ndiritu, S. W., Kassie, M., \& Shiferaw, B. (2014). Are there systematic gender differences in the adoption of sustainable agricultural intensification practices? Evidence from Kenya. Food Policy, 49, 117-127. https://doi.org/10.1016/j.foodpol.2014.06.010

Ngondjeb, Y., Nje, P., \& Havard, M. (2011). Déterminants de l'adoption des techniques de lutte contre l'érosion hydrique en zone cotonnière du Cameroun. Revue d'Elevage et de Médecine Vétérinaire des Pays Tropicaux, 64(1-4), 9-19. https://doi.org/10.19182/remvt.10120

Nyakatawa, E. Z., Reddy, K. C., \& Sistani, K. R. (2001). Tillage, cover cropping, and poultry litter effects on selected soil chemical properties. Soil and Tillage Research, 58, 69-79. https://doi.org/10.1016/S0167-1987 (00)00183-5

Nyangena, W., \& Juma, O. M. (2014). Impact of improved farm technologies on yields: the case of improved maize varieties and inorganic fertilizer in Kenya. Environment for development (Discussion paper series). Nairobi, Kenya.

Peigné, J., Ball, B. C., Roger-Estrade, J., \& David, C. (2007). Is conservation tillage suitable for organic farming? A review. Soil Use and Management, 23(2), 129-144. https://doi.org/10.1111/j.1475-2743.2006.00082.x

Scherr, S. J., \& Yadav, S. N. (1996). Land degradation in the developing world: Implications for food, agriculture, and the environment to 2020. Food, Agriculture, and the Environment Discussion Paper 14. Washington, D.C., USA: International Food Policy Research Institute.

Tiwari, K. R., Sitaula, B. K., Nyborg, I. L. P., \& Paudel, G. S. (2008). Determinant of farmer adoption of introduced soil and water conservation technology in middle mountain watershed of central Nepal. Environmental Management, 42, 210-222. https://doi.org/10.1007/s00267-008-9137-z

Toko, I., \& Sinsin, B. (2008). Les phénomènes d'érosion et d'effondrement naturels des sols (dongas) du Parc national du $\mathrm{W}$ et leur impact sur la productivité des pâturages. Science et Changements Planétaires/Sécheresse, 19(3), 193-200.

WEF (World Economic Forum). (2010). Biodiversity and business risk-A global risks network briefing. A briefing paper for participants engaged in biodiversity related discussions at the World Economic Forum Davos-Klosters Annual Meeting, Cologne, Geneva, Switzerland.

\section{Copyrights}

Copyright for this article is retained by the author(s), with first publication rights granted to the journal.

This is an open-access article distributed under the terms and conditions of the Creative Commons Attribution license (http://creativecommons.org/licenses/by/4.0/). 